\title{
Internettet som personaliseret og socialt medie
}

\section{Christian Dalsgaard}

Post.doc.

Institut for Informations- og Medievidenskab, Aarhus Universitetet

\section{Indledning}

De nye netbaserede digitale medier, der ofte går under betegnelsen social software eller Web 2.0, har ændret anvendelsen af internettet, og på få år er anvendelsen af disse medier blevet meget udbredt. Først og fremmest er e-mail og World Wide Web1 blevet taget bredt i brug og har dermed suppleret den traditionelle "push"-formidling med en "pull"-dimension, der muliggør, at interesserede kan opsøge informationerne, når og hvor de $ø$ nsker det. Derudover er der de sidste par år fremkommet en række netbaserede teknologier, der muliggør social interaktion, aktiv deltagelse

\footnotetext{
${ }^{1}$ Fremover anvendes internettet synonymt med World Wide Web, hvorfor fokus ligger på web og ikke blot på internettets infrastruktur som kobling af computere.
} 
og egenproduktion. De mest udbredte teknologier er weblogs, wikier, sociale fællesskaber og sites til deling af digitale materialer (Freedman 2006; O'Reilly 2005; Dalsgaard 2006; Dalsgaard 2007). Disse teknologier har medført, at mediernes rolle har ændret sig.

Spørgsmålet, som artiklen vil stille er, hvordan internettet kan fungere som vidensmedie. Hvad er potentialerne i internettet til at formidle og konstruere viden, og hvilke karakteristiske egenskaber har internettet som vidensmedie? Artiklen argumenterer for, at nye former for vidensdeling og vidensformidling kan opstå gennem personaliserede og sociale medier. Målet at identificere en række centrale egenskaber ved internettet $\mathrm{i}$ egenskab af personaliseret og socialt vidensmedie. Samtidig vil artiklen diskutere, hvordan internettet som vidensmedie muliggør, at uddannelsesinstitutioner og kulturinstitutioner kan udvide deres virke ud over deres fysiske rammer og deres hjemmesider. Artiklen afsluttes med en diskussion, der har til hensigt at pege i retning af, hvordan institutioner kan anvende digitale vidensmedier.

\section{Digital formidling som imitation af}

\section{eksisterende praksis}

Internettet betragtet som ressource erstatter hverken uddannelsesinstitutioner eller kulturinstitutioner, men disse institutioner kan gentænke deres virke ud fra internettets muligheder. Dette er i nogen grad ved at ske. Museer og biblioteker er gået på nettet (Løssing 2008) og i dag anvender uddannelsesinstitutioner - fra grundskole til universitet forskellige netbaserede medier.

Institutionernes anvendelse af nye digitale medier er primært en simpel form for remediering (Bolter 2000), hvor institutionerne efterligner deres eksisterende praksis blot i nye medier. Biblioteker går online i form af digitale biblioteker, der organiserer materialer på samme måde som det fysiske bibliotek. Forskellen er primært, at det er lettere at søge og bestille materialer. Museer går online gennem online udstillinger, der på forskellig vis efterligner eller tilnærmer sig den fysiske udstilling (Løssing 2008). Endelig er uddannelsesinstitutioner gået online, mest gennemgribende i form af e-læring (Anderson \& Elloumi 2004; Paulsen 2003; Bang 2006). Uddannelsesinstitutioner tager ofte afsæt i deres eksisterende praksis i anvendelsen af digitale medier. Det mest udbredte eksempel er anvendelsen af e-læringssystemer, der i høj grad understøtter den eksisterende praksis. Andre eksempler er anvendelsen af videokonferencesystemer til at holde forelæsninger og podcasting af forelæsninger. Lidt firkantet sagt er de fysiske rammer blevet erstattet af hjemmesiders rammer. Jeg vil argumentere for, at ovenfor beskrevne brug $\mathrm{i}$ 
uddannelses- og kulturinstitutioner ikke udnytter mulighederne i nye digitale medier, og at de digitale medier samtidig muliggør en gentænkning af institutionernes virke, hvilket kan styrke læring og vidensformidling.

Parallelt med udviklingen inden for institutioner stiger anvendelsen af nye digitale medier i uformelle sammenhænge. Denne udvikling er udtryk for en radikalt anderledes mediebrug, og der er ifølge Sørensen (2005) en kløft, der adskiller denne brug fra mediebrugen i uddannelsesinstitutioner. Anvendelsen af internettet i det private er eksploderet de senere år. Netbaserede tjenester som Myspace, Facebook, YouTube, Twitter, del.icio.us, flickr, Wikipedia og weblogs har fået en enorm udbredelse. Der eksisterer over 100 mio. weblogs på verdensplan2, på syv år har brugere fra hele verden skrevet over 2 mio. artikler til den engelsksprogede encyklopædi Wikipedia, det amerikanske netfællesskab MySpace har over 100 mio. profiler 3 , og brugere af videotjenesten YouTube uploader dagligt mere end 50.000 videoer, mens brugere ser 100 mio. videoer om dagen 4 . Brugere anvender digitale medier til at kommunikere og socialisere (http://www.myspace.com, http://www.facebook.com, http://www.arto.com), til at anmelde og diskutere forskellige produkter (http://www.hifi4all.dk, http://www.dpreview.com), til at søge hjælp og råd_(http://www.netdoktor.dk), til at anmelde film (http://www.imdb.com), musik (http://ww.last.fm), bøger (http://www.amazon.com) og spisesteder (http://www.mangospot.dk), til at se og udveksle billeder (http://www.flickr.com), videoer (http://www.youtube.com), til at dele præsentationer (http://www.slideshare.net), til at skrive og læse om andre (http://www.blogger.com, http://www.wordpress.org), til at dele favorithjemmesider (http://del.icio.us/, www.furl.net), etc. Denne anvendelse af digitale medier er udryk for, at der udspiller sig en bestemt form for kultur på internettet (Hull 2003; Willet \& Sefton-Green 2003; Sørensen et al. 2007). En stor del af denne udbredte anvendelse kan kategoriseres som underholdning, men visse brugsmønstre er samtidig udtryk for nye former for vidensformidling. Det indebærer, at uddannelsesinstitutioner og kulturinstitutioner kan lære noget af at studere de måder, hvorpå brugere i uformelle sammenhænge anvender internettet til at lære og konstruere viden. Ikke mindst er der store potentialer $\mathrm{i}$ at forsøge at blive en del af det brugsscenarium eller den kultur, der udspiller sig på internettet (Hull 2003). Derfor vil jeg betragte disse brugsscenarier i lyset af læring og videnskonstruktion og betragte teknologierne ud fra optikken vidensmedier.

2 http://technorati.com/about/ 


\section{Vidensmedier}

Artiklens forståelse af digitale vidensmedier baserer sig på en sociokulturel forståelse. Ifølge denne forståelse eksisterer viden i individets udførelse af handlinger - og ikke i et formidlet indhold af viden eller i materialer. Derudover knytter viden sig til kontekster, situationer og sociale praksisser, hvorfor også dialogisk kommunikation spiller en central rolle for individets konstruktion af viden (se den indledende artikel i dette tidsskriftsnummer).

På baggrund af den sociokulturelle medieforståelse flyttes fokus for behandling af medier fra mediet selv til mediets funktion. Det indebærer, at individets anvendelse bliver udgangspunktet for at karakterisere et medie. Fokus bliver med andre ord, hvilken rolle mediet spiller i relation til individets aktiviteter.

Forståelsen af vidensmedier som medier, der anvendes af individet til konstruktion af viden, indebærer, at tilrettelæggelse af vidensmedier skal fokusere på individets aktiviteter (Dalsgaard 2007). Det betyder ikke, at medier relativiseres, idet de ikke kan karakteriseres i sig selv. Medier kan i stedet karakteriseres og differentieres ud fra, hvordan de understøtter forskellige aktiviteter. Ud fra denne forståelse karakteriseres medier ikke ud fra egenskaber i dem selv, men i relation til, hvordan disse egenskaber understøtter forskellige aktiviteter 5 . Ud fra den sociokulturelle medieforståelse flyttes fokus ikke alene til kommunikation, men mere bredt til brugerens aktiviteter. Ud fra et uddannelsesperspektiv skriver Lukács (2007), at nye digitale medier imidlertid åbner for andre muligheder:

\section{"New digital media offer more possibilities for non-linear, personal and collaborative use of educational media content." (Lukács 2007: 207)}

Når fokus flyttes fra medier som transmissionsmedier til mediers understøttelse af brugernes aktiviteter, knyttes medier til forskellige anvendelser i stedet for at inddele dem ud fra teknologier som tv, radio, avis, etc. Forskellige teknologier understøtter i varierende grad forskellige anvendelser, hvorfor visse medier kan kategoriseres entydigt. For internettet er det imidlertid ikke tilfældet. Idet internettet som tidligere beskrevet kan efterligne alle andre medier, udfordrer internettet medieforståelsen (Finnemann 2005: 155, 161). Grundet internettets multiple anvendelsesmuligheder er det gavnligt med en forståelsesramme, der ikke definerer hele internettet som ét medie.

\footnotetext{
${ }^{5}$ Dette indebærer, at artiklen ikke diskuterer mediers betydning for samfundet som helhed, men derimod udelukkende mediers betydning for individet.
} 
Ud fra ovenstående medieforståelse vil jeg diskutere internettets særlige kvaliteter i forhold til vidensformidling og læring. Spørgsmålet er - på baggrund af det sociokulturelle vidensbegreb - hvilke kvaliteter der er centrale for internettet i egenskab af vidensmedie. Jeg vil argumentere for, at internettet som vidensmedie har unikke egenskaber, der knytter sig til internettets potentiale som personaliseret og socialt medie (Dalsgaard 2009). Disse to karakteristika ved mediet kan ikke adskilles fuldstændig fra hinanden, men de understreger forskellige pointer i anvendelsen af internettet som vidensmedie. I artiklen vil jeg argumentere for, at internettets egenskaber som personaliseret og socialt vidensmedie er narrowcasting og selektion, synkron og asynkron kommunikation, synlighed og indirekte kommunikation og kobling af mennesker og information.

\section{Personaliserede og sociale vidensmedier}

Ifølge det sociokulturelle vidensbegreb tager læring udgangspunkt i individets situation eller kontekst og i individets aktiviteter. Derfor er det centralt, at vidensmedier er personaliserede i den forstand, at de er målrettet individet, og at de muliggør, at individet aktivt kan tage dem i brug. Vidensmedier skal som udgangspunkt understøtte individets aktiviteter. Personaliserede vidensmedier skal ses i modsætning til redigerede udsendelser, programflader, etc., hvor alle har den samme indgang til mediet og til indhold. I stedet skal det være muligt for individet at tilrettelægge et personaliseret indhold.

Inden for e-læring er personalisering de senere år begyndt at spille en rolle primært som modstykke til centraliserede e-læringssystemer. Modstykket har form af begrebet Personal Learning Environments (PLE), der dækker over værktøjer, der giver den studerende mulighed for at konstruere sit eget læringsmiljø (Wilson et al. 2006; Attwell 2007). Attwell (2007) skriver om PLE:

\footnotetext{
"The idea of a Personal Learning Environment recognises that learning is continuing and seeks to provide tools to support that learning. It also recognises the role of the individual in organising their own learning. Moreover, the pressures for a PLE are based on the idea that learning will take place in different contexts and situations and will not be provided by a single learning provider. Linked to this is an increasing recognition of the importance of informal learning." (Attwell 2007)
} 
PLE skal ikke betragtes som ét system, men har i stedet form af individets personlige samling af forskellige værktøjer (Attwell 2007; Dalsgaard 2006). Som Attwell (2007) skriver, bevæger PLE-tankegangen sig ud over uddannelsesinstitutionernes rammer i en erkendelse af, at læring via internettet ikke eksklusivt tilhører uddannelsesinstitutioner. Netop i egenskaben personlige læringsmiljøer, der sammenstykkes af forskellige tjenester, knytter PLE sig til uformelle læringssituationer og livslang læring.

Endelig indebærer den sociokulturelle forståelse, at viden knytter sig til individets kontekst, hvilket indebærer, at informationsbehov er kontekstafhængige. Personalisering af vidensmedier indbefatter derfor også kontekstualisering, hvilket betyder, at information knyttes til individets øjeblikkelige kontekst, også forstået som fysisk kontekst. Vidensmedier skal være kontekstuelle og samtidige ved at tilpasse sig omgivelserne og præsentere sig i situationen. Digitale medier muliggør, at viden kan formidles ud over institutioners fysiske rammer og placeres i nye situationer. Et simpelt eksempel på kontekstuel information er informationsstandere placeret i skove eller ved turistattraktioner. Personalisering og kontekstualisering af information skal ses i modsætning til - og som supplement til - ikke mindst fysiske samlinger som museer og biblioteker. Personaliserede og kontekstuelle medier kan bringe information og materialer ud i nye sammenhænge.

Sociale vidensmedier skal ses som en forlængelse af og samtidig som et middel til personalisering. Det sociokulturelle vidensbegreb understreger vigtigheden af social interaktion for individets tilegnelse af viden. Derfor skal vidensmedier være sociale. Imidlertid er social interaktion et bredt begreb, der kan dække over mange kommunikationsformer. Med baggrund i den sociokulturelle tilgang er bestemte former for social interaktion centrale for videnskonstruktion.

Medier kan først og fremmest fungere som sociale vidensmedier, hvis de muliggør dialog og samarbejde. Det vil sige social interaktion, hvor individet indgår i tovejskommunikation og i et direkte samspil med andre. Dialog og samarbejde understøtter, at individet ikke blot tilegner sig viden gennem materialer, men også ved at indgå i dialog med andre mennesker. Dialog og eventuelt samarbejde skal medvirke til at sikre individets deltagelse, hvilket betyder, at der i dialog og samarbejde netop også er tale om personalisering. I modsætning til transmissionsmedier tager medier for tovejs-kommunikation udgangspunkt i individets egne spørgsmål, og dermed kan individet få personaliseret feedback. Det indebærer, at sociale vidensmedier skal betragtes som en forlængelse af personalisering, idet socialisering involverer og er et middel til personalisering. 
Ud fra sociokulturel teori findes imidlertid en anden form for kommunikation, der er central for videnskonstruktion og læring. Som beskrevet ovenfor eksisterer viden i individets udførelse af handlinger, der finder sted inden for en kollektiv sociokulturel praksis af andre individer. Det indebærer, at viden afhænger af og relaterer sig til andre individers handlinger. Andre individers handlinger har betydning for forståelsen af egne handlinger, hvorfor individets indsigt $\mathrm{i}$ og bevidsthed om andre individers handlinger har en betydning for videnskonstruktion. Denne bevidsthed om andres handlinger kan medvirke til individets refleksion over egne handlinger i relation til andres. Selvom dialog og samarbejde understøtter bevidsthed om og indsigt $\mathrm{i}$ andres handlinger, er de ikke de eneste midler til at støtte denne form for kommunikation. Bevidsthed og indsigt understøttes også af en kommunikationsform, hvor individer "passivt" kan følge med i hinandens handlinger. Som jeg vil argumentere for nedenfor, har internettet et særligt potentiale i denne henseende.

\section{Internettet som vidensmedie}

Spørgsmålet er, hvilke egenskaber internettet har som personaliserede og sociale vidensmedier. For at kunne diskutere, hvordan internettet kan fungere som vidensmedie, er det først nødvendigt at undersøge, hvilke aktiviteter eller anvendelsesformer internettet muliggør. Ud fra denne tilgang er det muligt at analysere internettets særlige egenskaber ud fra et bruger- eller modtagerperspektiv - og ikke fra et teknologisk perspektiv. Samtidig er det muligt at skelne internettets kvaliteter fra kvaliteter hos andre medier.

Jeg vil fremhæve fire anvendelsesformer, hvor internettet har særlige egenskaber i relation til vidensformidling og læring: 1) Publikation og broadcasting, 2) dialog og samarbejde, 3) deltagelse i netværk og 4) deling af information. Der er ikke tale om en udtømmende liste over internettets anvendelsesformer, men de fire anvendelsesformer er udvalgt på baggrund af optikken om personaliserede og sociale medier, hvilket vil blive uddybet nedenfor. Med undtagelse af den tredje anvendelsesform understøttes de alle af andre medier. Inden for hver anvendelsesform har internettet imidlertid særlige egenskaber som personaliseret og socialt vidensmedie:

- Publikation og broadcasting: Narrowcasting og selektion

- Dialog og samarbejde: Synkron og asynkron kommunikation

- Deltagelse i netværk: Synlighed og indirekte kommunikation

- Deling af information: Kobling af mennesker og information

Med udgangspunkt i begreberne om personaliserede og sociale vidensmedier udmærker internettet sig ved narrowcasting og selektion til publikation og broadcasting. Dialog og samarbejde understøttes af internettet i form af synkron og asynkron kommunikation. Deltagelse i 
netværk understøttes af internettet af synlighed og indirekte kommunikation. Endelig har internettet en unik egenskab til støtte af deling af information i form af en kobling af mennesker og information.

\section{Narrowcasting og selektion}

Internettet anvendes til publikation og broadcasting. Som udgangspunkt adskiller dette sig ikke fra traditionelle medier som radio, tv og aviser. En producent publicerer et indhold til modtagerne. Dog er der den forskel, at internettet - modsat eksempelvis tv og radio - muliggør en ikke-lineær og ikke programsat publikation. Gennem eksempelvis podcasting kan man høre udsendelser, når man vil, da de lagres på nettet. Men der er principielt set stadig tale om traditionel publikation eller broadcasting. Eksempler på netbaseret publikation og broadcasting er netaviser i form af hjemmesider (Falkenberg 2007), weblogs og podcasts.

Eksempler på traditionel publikation og broadcasting:

www.jp.dk

www.politiken.dk

www.dr.dk

www.berlingske, dk

http://googleblog.blogspot.com/

http://blog.tv2.dk/

www.podcast.au.dk

www1.sdu.dk/podcast

Derudover adskiller internettet sig fra traditionelle publikationsmedier, det det giver brugerne mulighed for selv kan publicere og broadcaste, hvilket med andre ord ikke er begrænset til aviser, tv-stationer og lignende.

Brugerne har i højere grad fået kontrol over og mulighed for deltagelse i medierne:

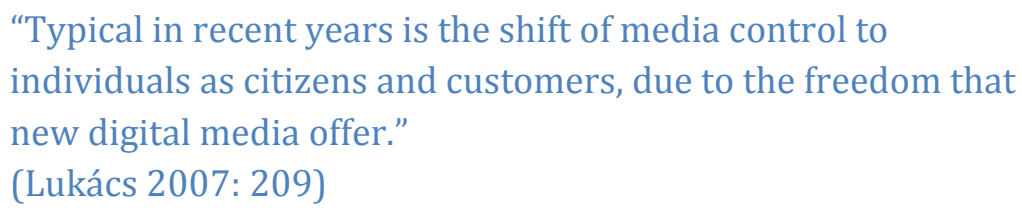

Dette er netop et udtryk for, at internettet muliggør personalisering af mediebrugen. Internettet, og digitale medier generelt, har et langt større potentiale end traditionelle medier til at skabe personaliseret indhold. 
Denne form for personalisering giver sig til udtryk på mange måder og gennemsyrer mange hjemmesider og tjenester på internettet:

"Til forskel fra avisen og værket vil et netsted (eller en del af et netsted) kunne være personaliseret (siderne, der vises, kan være "helt" eller delvis defineret af brugeren). Det kan spænde fra at være en præ-selektion af emner fra en større liste (aktier, nyheder om x), over til at være en indkøbsliste, hvor der for hver brugerdefineret valgt enhed kan udbydes mere, specifik information (f.eks. Amazon.com), til at være et særligt design af brugergrænsefladen, hvor udbyderen måske kun har defineret et logo og derudover blot tilbyder personaliseringsmuligheder."

(Finnemann 2005: 179)

Som Manovich (2001) skriver, er det unikt for, hvad Manovich betegner som "nye medier", at de ikke er statiske, men derimod foranderlige.

\footnotetext{
"Stored digitally, rather than in a fixed medium, media elements maintain their separate identities and can be assembled into numerous sequences under program control. [...] [I]nformation about the user can be used by a computer program to customize automatically the media composition as well as to create elements themselves."

(Manovich 2001: 36-37)
}

Lukács (2007) beskriver digitale mediers store potentiale til, hvad han betegner som "narrowcasting" og "personalised media services" (Lukács 2007: 201-203), der indebærer, at udbyderne tilbyder et differentieret indhold, der er målrettet forskellige brugere. Tjenester på internettet muliggør, at man på baggrund af sin brug af tjenesterne kan få leveret personaliseret indhold og foretage personaliserede søgninger. Et eksempel på narrowcasting er firmaer, der anbefaler yderligere produkter på baggrund af tidligere køb (se figur 1). 


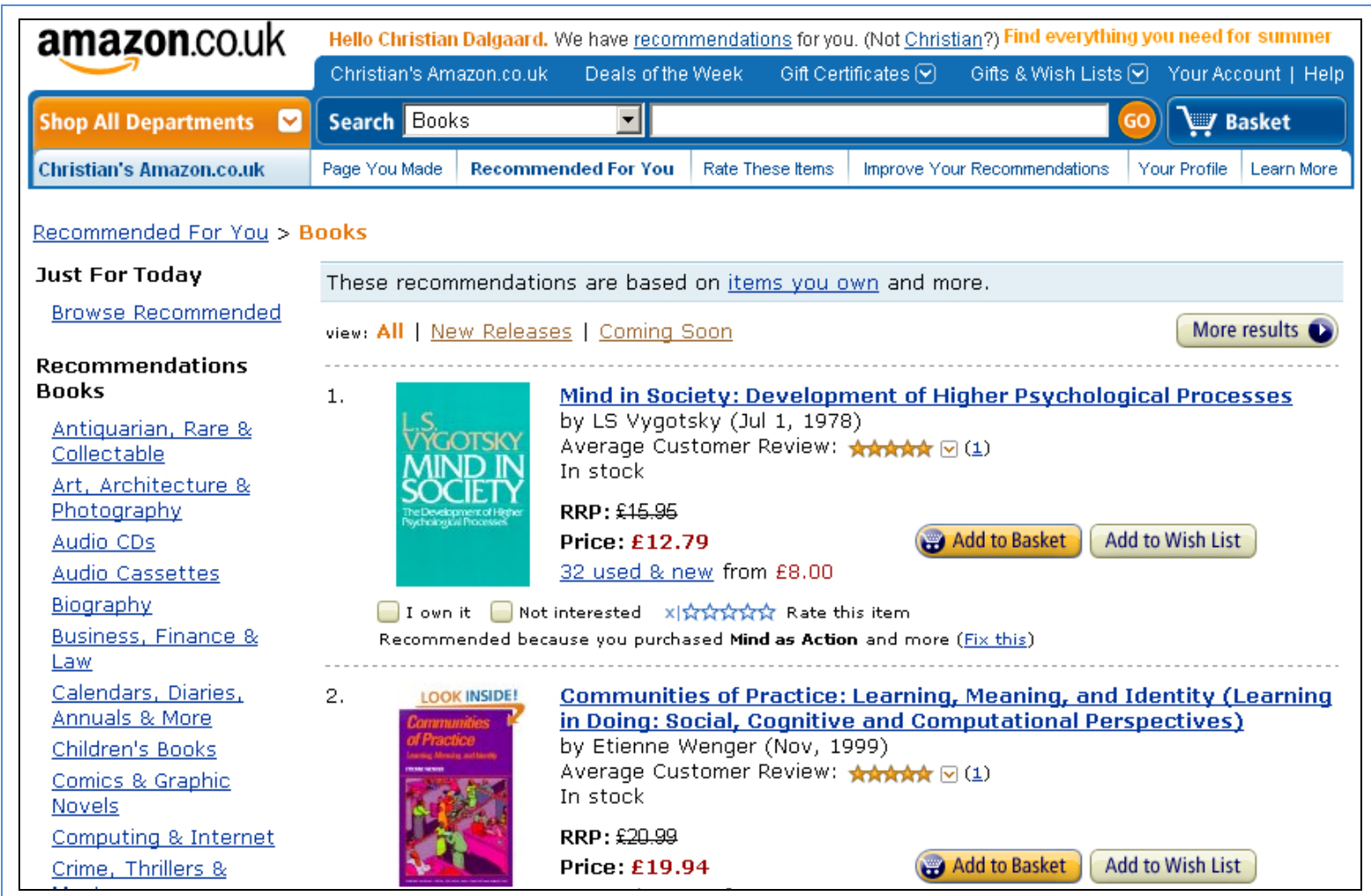

Figur 1. Eksempel på Narrowcasting. Amazon (http://www.amazon.co.uk) anbefaler bøger og andre materialer på baggrund af kundens tidligere indkøb.

Det mobile internet føjer et ekstra niveau til narrowcasting i form af muligheden for at kontekstualisere information. Ved brug af GPS og internettet kan information præsenteres ud fra et kendskab til individets fysiske placering såvel som ud fra personens profil eller ud fra, hvad individet søger i situationen. Udbydere har dermed mulighed for at narrowcaste på baggrund af individets fysiske placering.

"In the near future mobile technologies with built-in GPS devises
will make information available everywhere as both 'pull' and
'push' services"
(Bang 2008)

Hvor narrowcasting stadig har fokus på afsenderen og på, at afsenderen så at sige personaliserer eller målretter indhold, findes der en anden form for personalisering, som jeg vil betegne som selektion. Selektion muliggør brugerens egen tilrettelæggelse af indhold. Eksempelvis kan et individ via feed readers abonnere på rss-feeds fra udvalgte tjenester. Det muliggør, at man kan konstruere sin personaliserede nyhedstjeneste. En personaliseret nyhedstjeneste kan f.eks. bestå af sportsnyheder fra samtlige netaviser, af 
nyheder fra weblogs, af nye videoer inden for et bestemt emne, af billeder tagget med bestemte ord, etc. Ud over nyheder i tekst er det også muligt at abonnere på lyd- og videoudsendelser i form af radio- og videopodcast. Der er ikke tale om, at en afsender broad- eller narrowcaster differentieret indhold til forskellige målgrupper. I stedet er fokus på modtageren, der selv selekterer og sammensætter sit indhold - potentielt fra forskellige afsendere. Det indebærer, at udbydere ikke skal tænke i at målrette indhold til forskellige målgrupper, men i stedet skal muliggøre, at modtageren selv kan tilrettelægge indholdet individuelt - og i sammenhæng med indhold fra andre udbydere. Et eksempel er netop anvendelsen af rss- syndikering, der gør det muligt for individet at tilrettelægge sin egen nyhedstjeneste (se figur 2).

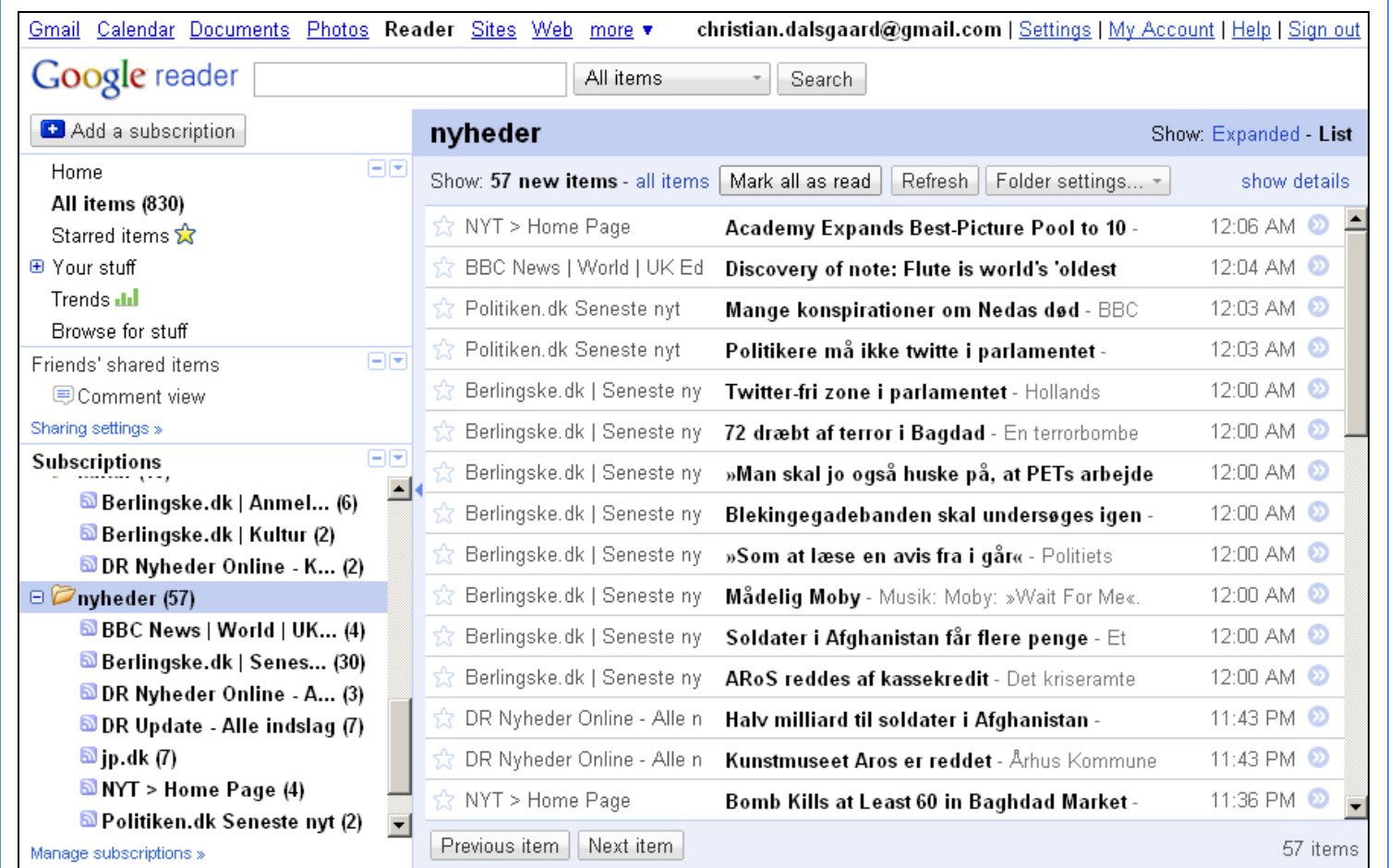

Figur 2. Eksempel på selektionen. Feedreadere såsom Google Reader (www.google.com/reader) muliggør, at brugeren kan oprette en personlaiseret nyhedstjeneste, der eksempelvis består af nyheder fra forskellige netaviser.

\section{Synkron og asynkron kommunikation}

Ud over publikation og broadcasting giver internettet mulighed for brugernes sociale deltagelse i form af dialog og samarbejde. Internettet anvendes som medie for social interaktion. Med andre ord er internettet ikke blot et transmissionsmedie, men et dialogmedie, der giver mulighed for tovejs-kommunikation. Samtidig giver internettet mulighed for at samarbejde om produktion af indhold. Eksempler på dialog og samarbejde på internettet er diskussionsfora eller online communities, weblogs og wikier. Internettet muliggør, at brugeren kan deltage i diskussioner og 
stille spørgsmål på baggrund af sin egen situation. Til forskel fra andre medier rummer internettet mulighed for både synkron og asynkron kommunikation og samarbejde. Synkron kommunikation er primært i form af internettelefoni og chat, og asynkron i form af e-mail og diskussionsfora. Samtidig findes applikationsdelingsværktøjer, der muliggør asynkront (og delvist synkront) samarbejde. Yderligere er internettet medvirkende til at nedbryde en skelnen mellem asynkron og synkron, eftersom internettet muliggør kommunikation i kontinuet mellem synkron og asynkron. Eksempelvis kan chat være delvist asynkron, mens e-mail i visse situationer kan nærme sig synkron kommunikation. Endelig er vi i øjeblikket vidner til en sammensmeltning af synkron og asynkron kommunikation. Eksempelvis integrerer Google Wave (http://wave.google.com/) - der i skrivende stund er under udvikling muligheden for synkron og asynkron kommunikation og samarbejde i samme værktøj.

Ud fra optikken om personaliserede og sociale vidensmedier er potentialet, at synkron og asynkron kommunikation og samarbejde giver individet fleksible muligheder for at deltage i kommunikations- og samarbejdsrum, hvor han/hun kan få personaliseret feedback på egne spørgsmål og konstruere ny viden i fællesskab med andre. Et eksempel er de utal af online diskussionsfora eller communities, hvor medlemmerne diskuterer forskellige, ofte specifikke emner, og hvor man spørger hinanden til råds (se figur 3).

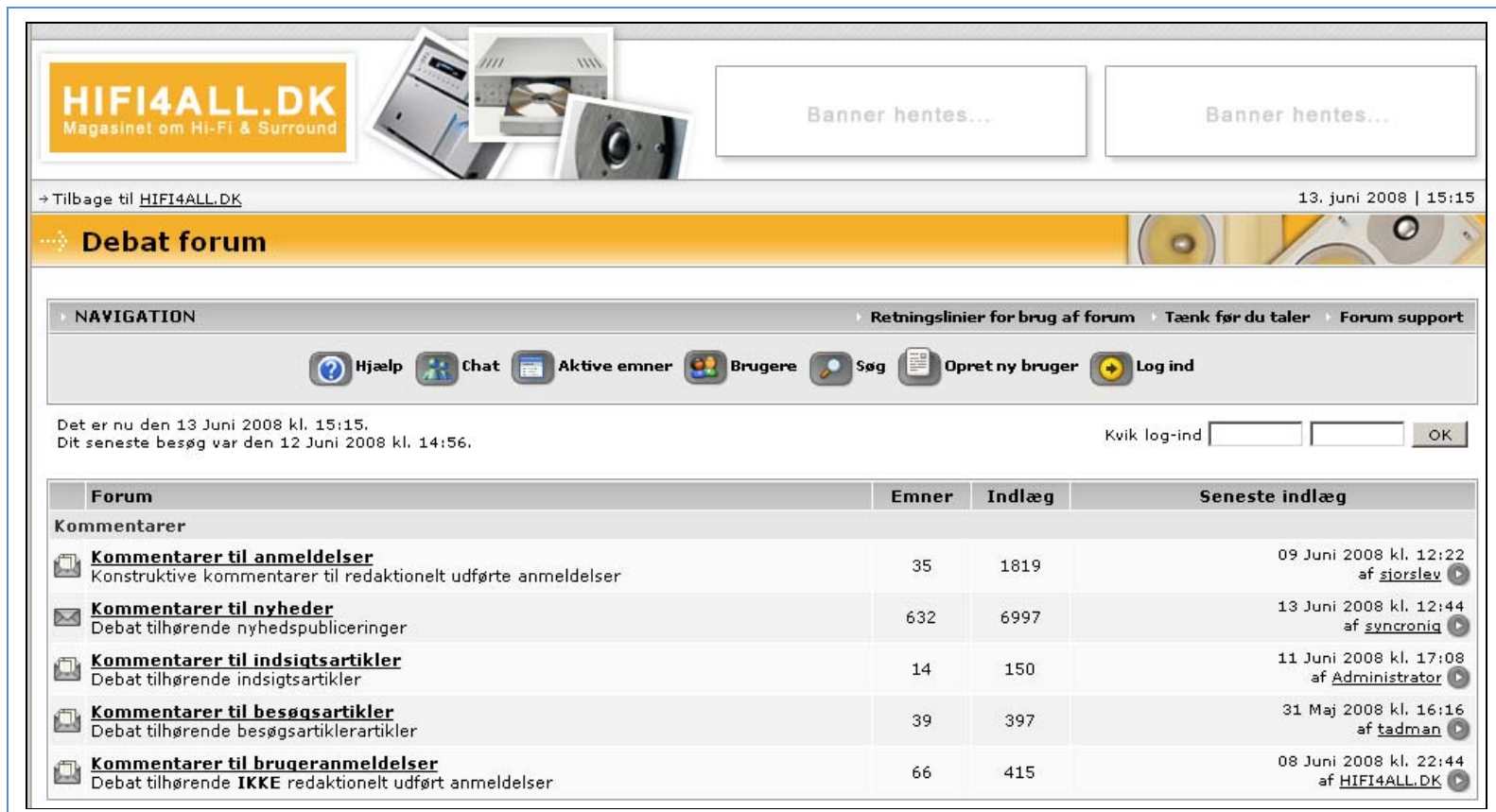

Figur 3. Eksempel på asynkron kommunikation i et diskussionsforum (http://hifi4all.dk) 
Eksempler på dialog og samarbejde:

http://www.wikipedia.org

http://www.downes.ca/

http://janeknight.typepad.com/pick/

http://www.wordpress.org

http://www.blogger.com

http://wordpress.org/support/

http://www.hifi4all.dk

http://www.clonemetal.dk/phpBB2/index.php

http://www.gamesection.dk/

http://www.soundcheck.dk/

http://www.aage.dk/

http://www.filmz.dk/forum/

\section{Synlighed og indirekte kommunikation}

Social interaktion på nettet indebærer ikke nødvendigvis dialog og samarbejde. En udbredt anvendelse af nettet har form af deltagelse i netværk især i form af sociale fællesskaber ("social networking sites") som Facebook og Myspace, gennem netværk af weblogs eller gennem mikroblogging som Twitter. Deltagelse i netværk er en unik egenskab, som internettet ikke deler med andre medier, mens dialog og samarbejde også er muligt gennem andre teknologier som telefonen.

Ud fra optikken om sociale vidensmedier vil jeg argumentere for, at netværk på internettet har et særligt potentiale til at understøtte synlighed og indirekte kommunikation. Begreberne om synlighed og indirekte kommunikation flytter fokus fra netværksdannelse eller "networking", der ofte fremhæves som potentialer i sociale netværk. I stedet sætter begreberne fokus på den særlige relation, der er mellem mennesker i sociale netværk. Sociale netværk er først og fremmest interessante for optikken om vidensmedier, idet sociale netværk tager udgangspunkt i individet. Nøglen til deltagelse i netværk er, at individet kan skabe en repræsentation og dermed en tilstedeværelse i mediet i form af en personlig profil eller hjemmeside. Denne danner udgangspunkt for at koble sig til andres profiler eller sider, og dermed skabes netværk. Resultatet er, 
at hvert individ udvikler sit eget unikke, personaliserede netværk af relationer. De mest udbredte eksempler på netværk er sociale fællesskaber, men weblogs kan tjene samme funktion, når de kobles i netværk.

Derudover er sociale netværk på internettet interessante for begrebet om vidensmedier, idet netværkene muliggør, at individer kan følge med i ændringer på hinandens profiler eller hjemmesider, der er synlige for andre i netværket. I sociale netværk er der dermed tale om en anderledes kommunikationsform end i diskussionsfora, hvor kommunikation finder sted i et delt forum. Kommunikationen i sociale netværk er et spørgsmål om at opdatere sin profil eller hjemmeside og at følge med i andres opdateringer. Det vil sige, at kommunikationen i høj grad baserer sig på synlighed af de personlige profiler eller hjemmesider og på den form for indirekte kommunikation, der opstår, når individer "passivt" følger med i hinandens opdateringer. Det indebærer, at kommunikationen ikke nødvendigvis er dialogisk. Synlighed og indirekte kommunikation er relevante egenskaber for internettet som vidensmedie, idet individets indsigt $\mathrm{i}$ andre individers handlinger som nævnt kan styrke refleksion over egne handlinger.

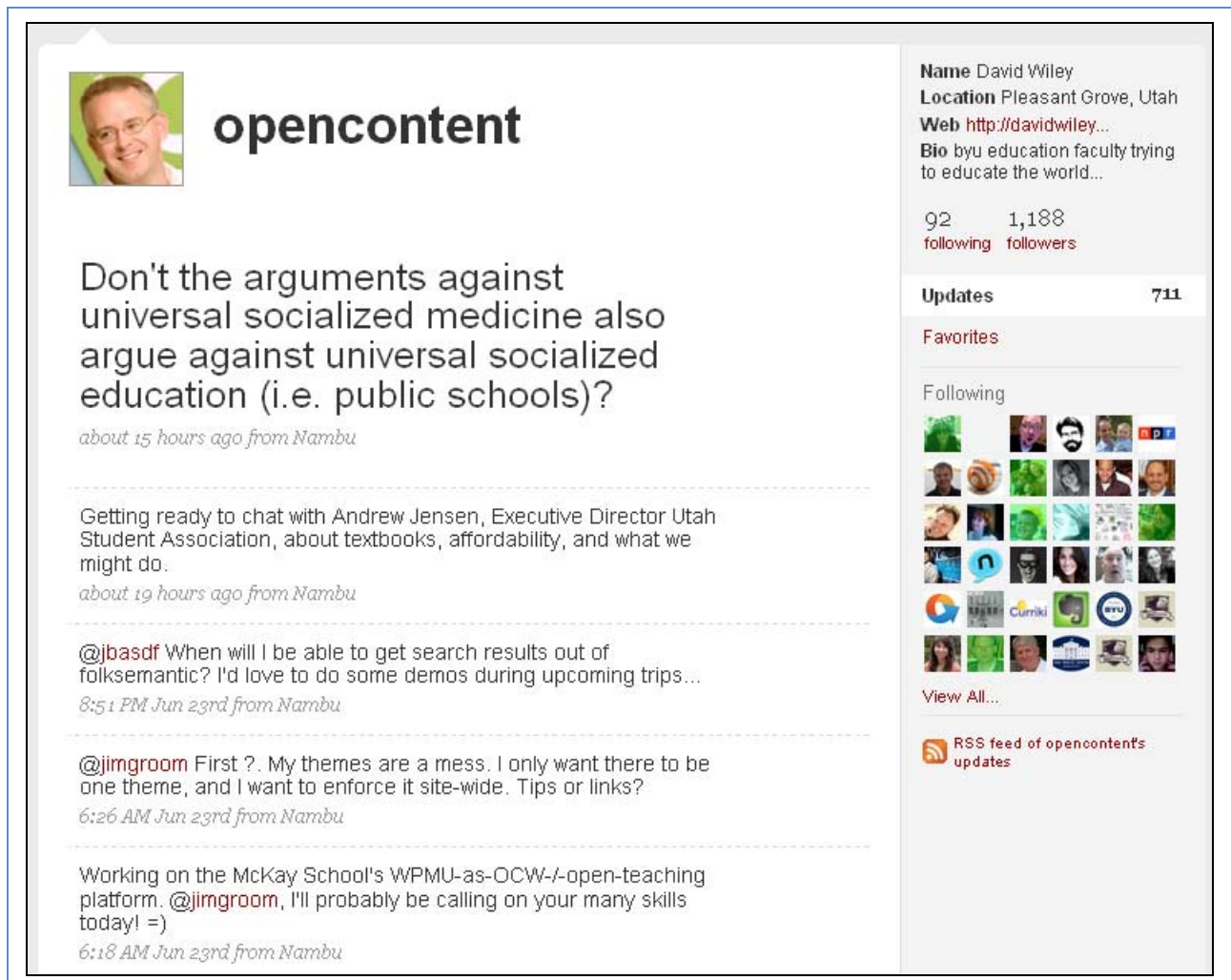

Figur 4. Eksempel på synlighed og indirekte kommunikation i Twitter (http://twitter.com/opencontent). Til venstre ses profilens indlæg og til højre ses billeder af personer, der følger denne profil. 
Eksempler på deltagelse i netværk:

$\underline{\text { www.facebook.com }}$

www.bebo.com

$\underline{\text { www.myspace.com }}$

www.arto.com

www.linkedin.com

http://pulse.plaxo.com

Kobling af mennesker og information

Den sidste aktivitet, jeg vil fremhæve, er deling af information. Ud over at fungere som medie for social interaktion, kan internettet fungere som lager af digitalt indhold, der i princippet kan tilgås og kopieres af alle. Eksempler på anvendelse af internettet til deling af information er digitale biblioteker, databaser, media sharing services (Youtube og Flickr) og social bookmarking. En traditionel deling af information gennem samlinger eksempelvis i form af biblioteker overføres til internettet gennem digitale biblioteker, hvor materialer kategoriseres fra centralt hold. Denne form for lagring af information og materialer adskiller sig ikke kvalitativt fra traditionelle, fysiske biblioteker, men er primært et spørgsmål om øget hastighed og tilgængelighed.

Dog er der en central forskel, som Manovich (2001) pointerer. Den digitale database muliggør, at ressourcer kan blive præsenteret og navigeret i på et utal af måder. Manovich (2001: 221) taler om "the anti-narrative logic of the Web" og skriver:

\footnotetext{
"After the novel, and subsequently cinema, privileged narrative as the key form of cultural expression of the modern age, the computer age introduces its correlate - the database. Many new media objects do not tell stories; they do not have a beginning or end; in fact, they do not have any development, thematically, formally, or otherwise that would organize their elements into a sequence. Instead, they are collections of individual items, with every item possessing the same significance as any other. (Manovich 2001: 218)
}

I forhold til deling af materialer adskiller internettet sig dog mest markant fra fysiske biblioteker på det punkt, at brugerne har mulighed for at bidrage til deling. Først og fremmest kan brugerne bidrage til at 
kategorisere materialer (gennem tagging). Derudover har brugerne mulighed for at dele egen information og egne materialer. Dette indebærer, at materialer ikke blot kategoriseres fra én central institution, men får en mangfoldig kategorisering (folksonomy). Samtidig indebærer det, at information kan knyttes til individer. Dette er netop kernen i et centralt potentiale i internettet som socialt vidensmedie, eftersom det muliggør en kobling af mennesker og information. En unik egenskab ved de nye digitale medier er netop koblingen af mennesker og information; det vil sige en kobling af social interaktion og materialer. Som Finnemann (2005) påpeger:

\section{"Nettets mest afgørende, grundlæggende og unikke egenskab er ikke interaktiviteten, men derimod integrationen af højhastighedskommunikation og vidensarkiv." (Finnemann 2005: 143)}

Det unikke består $\mathrm{i}$, at det på internettet er muligt at repræsentere information og materialer i sociale netværk. Eksempelvis i objekt- eller materialecentrerede netværk, hvor deling af materialer er i fokus (YouTube, flickr, del.icio.us, last.fm) og i personcentrerede sociale netværk, hvor udgangspunktet er social interaktion, men hvor individer deler og viser forskellige materialer som musik og film (weblogs, Facebook, Myspace).

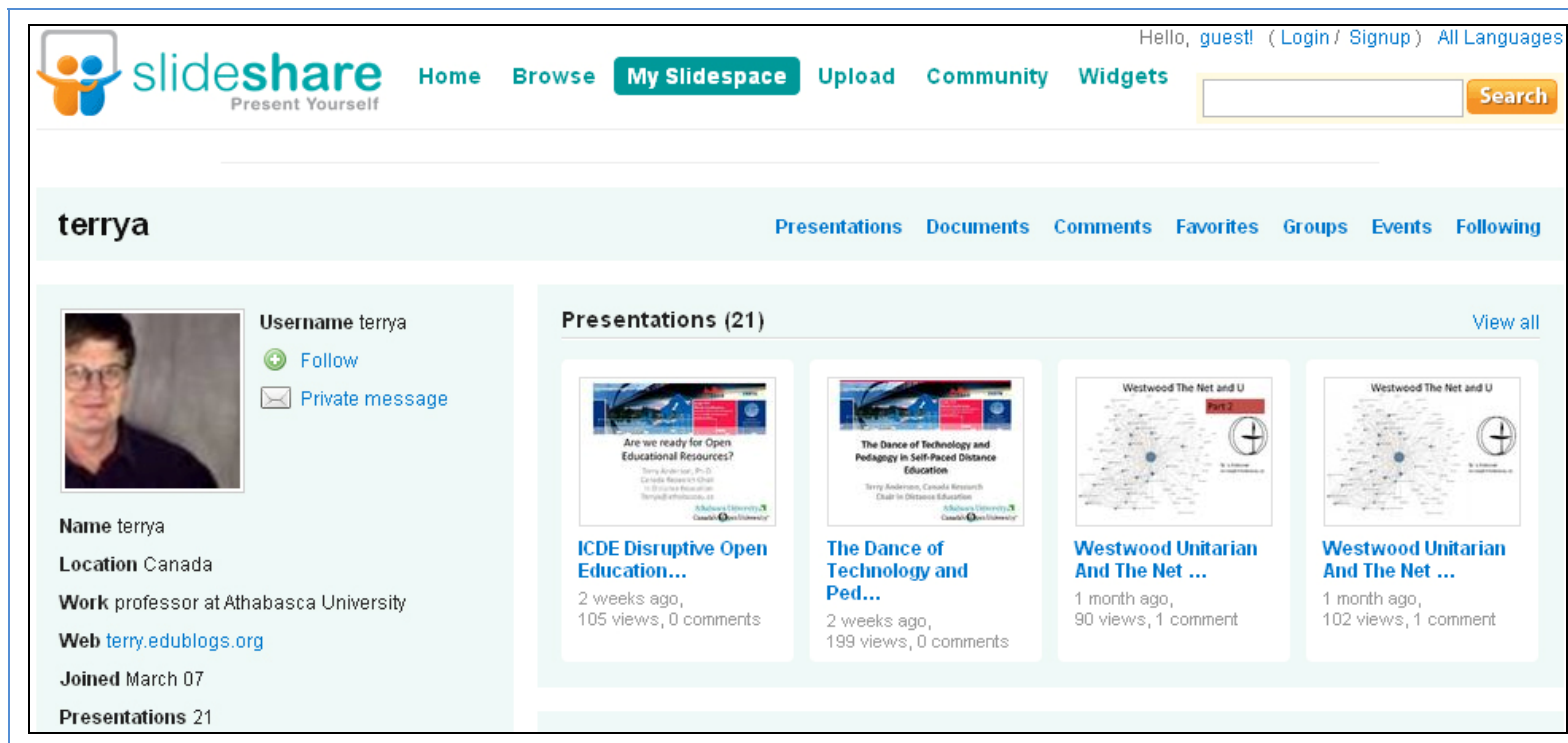

Figur 5. Eksempel på kobling af menneske og information i SlideShare. Præsentationer i slidehare er knyttet til en person (http://www.slideshare.net/terrya).

Koblingen af mennesker og information indebærer, at information og materialer kan spredes i sociale netværk. Denne form for et socialt 
vidensmedie skal ses i modsætning til eksempelvis fysiske såvel som traditionelle digitale biblioteker. Et fysisk bibliotek har kun én bog, der befinder sig ét sted. Digitale biblioteker kan indeholde et uendeligt antal kopier. Der sker imidlertid noget kvalitativt nyt i kombinationen af information og social interaktion. Der er så at sige tale om, at der lægges et socialt lag oven på databaser, hvilket muliggør en social navigation i ressourcerne i databaser (jvf. Manovich ovenfor). Information placeres i sociale kontekster, hvilket er kvalitativt anderledes end kategorisering og lagring i biblioteker. I stedet for at finde materialer gennem søgemaskiner, finder man dem gennem sit personlige netværk. En væsentlig egenskab ved digitale mediers kobling af information og social interaktion er, at det samme materiale kan være placeret i et utal af forskellige sammenhænge og sociale netværk. Da netværk som beskrevet ovenfor er personlige, indebærer organisering af materialer i sociale netværk en personaliseret indgang til information og materialer på nettet. Individet finder på denne måde information gennem sine relationer.

Eksempler på deling:

www.youtube.com

$\underline{\text { www.flickr.com }}$

www.slideshare.net

http://del.icio.us

$\underline{\text { www.furl.net }}$

\section{Konklusion: Perspektiver for internettet som vidensmedie}

Egenskaberne som personaliseret og socialt medie berettiger at betegne internettet som et vidensmedie. Som personaliseret og socialt vidensmedie giver internettet institutioner nye muligheder for at bevæge sig ud over en simpel form for remediering, der efterligner en eksisterende praksis og mediebrug. I dette afsluttende afsnit vil jeg pege i retning af måder, hvorpå institutioner kan anvende internettet som vidensmedie. Artiklens diskussion af personaliserede og sociale vidensmedier peger på, at uddannelsesinstitutioner og kulturinstitutioner har mulighed for at anvende internettet til at tilbyde information i form af materialer såvel som personer i situationer og sammenhænge, der bevæger sig ud over institutionernes tilrettelagte uddannelsesforløb, udstillinger og hjemmesider. Kernen i institutioners bevægelse ud over egne rammer går gennem tilrettelæggelse af vidensmedier, der understøtter individets egne aktiviteter. 
Udfordringen ligger i, at institutioner både bevæger sig ud over deres fysiske rammer, men også ud over rammerne for deres hjemmesider. De fleste af artiklens ovenstående eksempler på personaliserede og sociale medier stammer fra uformel, ikke-institutionaliseret brug af internettet. Eksemplerne kan ikke overføres direkte til institutionel brug, men de fremhæver en række principielle anvendelsesformer, som institutioner kan lade sig inspirere af. Et par eksempler kan illustrere perspektiverne i institutioners anvendelse af internettet til vidensformidling og læring.

Ført og fremmest kan institutioner arbejde med narrowcasting og selektion. Det er ikke mindst oplagt for biblioteker, der kan tilbyde brugerne personlige sider, der eksempelvis kan danne baggrund for at bringe eller narrowcaste individuelle anbefalinger ud fra brugernes præferencer. For visse museer vil det især være oplagt at narrowcaste ved hjælp af GPS-teknologi. Museer kan bringe information ud til fysiske beliggenheder. Det er teknisk muligt ved hjælp af teknologier som GPS og mobiltelefoner, at en turist på byvandring eksempelvis kan fremkalde museers information om bygninger, steder, etc., som han/hun besøger. For at bringe information og materialer ud over egne hjemmesider kan institutioner desuden tilbyde rss-feeds inden for forskellige områder; i bibliotekets tilfælde eksempelvis inden for genrer, emner, forfattere, etc. Dette vil muliggøre selektion, eftersom brugerne kan abonnere på personaliserede nyheder fra institutionerne (jvf. figur 2).

For institutioner ligger der ligeledes et potentiale i at arbejde med dialog og samarbejde i form af synkron og asynkron kommunikation. Ved hjælp af internettet har institutioner mulighed for at bevæge sig fra transmission og broadcasting til dialogisk kommunikation. Internettet giver institutioner nye muligheder for at indgå i dialog med brugere. Kommunikationsforum (http://www.kommunikationsforum.dk)er et eksempel på et ikkeinstitutionelt forum, hvor forskere bidrager til diskussion af kommunikationsrelevante emner sammen med ikke-forskere. Et andet eksempel er videnskab.dk (http://www.videnskab.dk), hvor forskere deltager i diskussioner og besvarer spørgsmål fra brugere.

Især universiteter kan styrke deres formidling gennem synlighed og indirekte kommunikation. Forskere kan være repræsenteret på internettet gennem personlige profiler eller hjemmesider. Et eksempel er weblogs, hvor forskere kan publicere nyheder, skrive om deres forskning, give deres mening til kende, etc. Der findes i dag i underkanten af 40 danske forskerblogs6, et eksempel er Lisbeth Klastrup, der har opretholdt en

\footnotetext{
${ }^{6}$ Antallet baserer sig på Bodil Christensen kortlægning af forskerblogs fra 2009 (http://diplom07.blogspot.com/2008/10/min-liste-over-danske-forskerblogs.html) og Lisbeth Klastrups løbende opdaterede liste over forskerblogs (http://www.klastrup.dk/forskerblogs/2006/12/liste-over-danske-forskningsblogs2.html).
} 
forskerblog siden 2001 (http://www.klastrup.dk). I mindre format kan forskere gøre sig synlige i form af mikro-blogging eksempelvis i Twitter (jvf. figur 4). Synligheden kan udvides ud over indlæg gennem synliggørelse af forskeres publikationer, litteraturreferencer, oplæg, etc. gennem tjenester som CiteUlike (http://www.citeulike.org), Delicious (http://del.icio.us) og SlideShare. Dermed får forskeren også en repræsentation på nettet af egne materialer og referencer, hvilket knytter an til den sidste egenskab ved internettet som personaliseret og socialt vidensmedie i form af kobling af mennesker og information.

Institutioner kan tænke i deling af information gennem kobling af mennesker og information. Udfordringen består i at flytte digitale materialer ud af institutionerne og gøre dem anvendelige i nye sammenhænge. Det indebærer, at materialer skal kunne flyttes fra institutionernes egne tjenester og dermed blive en del af forskellige fællesskaber og netværk på internettet. Uddannelsesinstitutioners anvendelse af YouTube og SlideShare er eksempler på, at institutionernes materialer optræder side om side med andre materialer (jvf. figur 5). Ligeledes vil forskere kunne anvende social bookmarking-tjenester som Delicious og CiteUlike til at præsentere foretrukne hjemmesider og deres litteraturreferencer. Dermed præsenteres denne information i tilknytning til den enkelte forsker. For biblioteker og museer er det oplagt at muliggøre integration i eksterne tjenester såsom weblogs og sociale fællesskaber, hvori institutionernes materialer knyttes til forskellige brugere. Eksempler for bibliotekers vedkommende er LibraryThing (http://www.librarything.com) og Shelfari (http://www.shelfari.com), der muliggør integration af eksisterende information fra biblioteker i eksterne hjemmesider. Dette indebærer, at bibliotekers information bliver tilknyttet forskellige brugere og dermed gjort synlig på personlige hjemmesider og $\mathrm{i}$ sociale netværk. Potentialet ligger i, at biblioteker kan anvende sociale netværk til at sprede og "organisere" information. Brugere vil kunne finde materialer gennem sociale netværk som supplement til at søge på biblioteket. Målet er en kobling af information og social interaktion gennem opbygning af sociale netværk omkring bibliotekets materialer (tilsvarende eksempelvis YouTube eller SlideShare, jvf. figur 5). Udfordringen består i at flytte digitale materialer ud af institutionerne i forskellige netværk, således at materialerne kan repræsenteres i forskellige sammenhænge.

\section{Litteratur}

Anderson, Paul (2007). What is Web 2.0? Ideas, technologies and implication for education. JISC.

http://www.jisc.ac.uk/media/documents/techwatch/tsw0701b.pdf 
Anderson, Terry \& Elloumi, Fathi (eds.) (2004). Theory and Practice of Online Learning. Athabasca University.

http://cde.athabascau.ca/online_book/

Atwell, Graham (2007). Personal Learning Enviornments - the future of eLearning?, eLearning Papers, Vol. 2(1). www.elearningpapers.eu.

Bang, Jørgen (2006). eLearning reconsidered. Have e-learning and virtual universities met the expectations?, elearningeuropa.info.

http://www.elearningeuropa.info/directory/index.php?page=doc\&doc $\mathrm{id}=7778 \&$ doclng $=6$

Bang, Jørgen (2007). Biografreklamer som kulturarv. Dansk Reklamefilm. http://www.reklamefilm.statsbiblioteket.dk/biografreklamer_og_kultur JB.pdf

Bang, Jørgen (2008). Enhancing learning: Potentials of virtual libraries and repositories. EUNIS 2008 Conference Proceedings.

Bolter, Jay David \& Grusin, Richard (2000). Remediation: Understanding New Media. The MIT Press.

Dalsgaard, Christian (2006). Social software: E-learning beyond learning management systems, European Journal of Open, Distance and Elearning, vol. $2006 \mathrm{nr} .2$.

http://www.eurodl.org/materials/contrib/2006/Christian_Dalsgaard.h tm

Dalsgaard, Christian (2007). Åbne læringsressourcer - mod en sociokulturel teori om læringsressourcer. Ph.d.-afhandling, Informations- og Medievidenskab, Aarhus Universitet. http://person.au.dk/fil/5991913/Phd-afhandling_Dalsgaard.pdf.

Dalsgaard, Christian (2008). Social networking sites: Transparency in online education, EUNIS 2008 Conference Proceedings.

Dalsgaard, Christian (2009). From transmission to dialogue: Personalised and social knowledge media, MedieKultur, vol. 46, s. 18-33.

Falkenberg, Vidar (2007). Online newspapers as newspapers online extending the concept of 'newspaper', The Impact of Internet on the Mass Media in Europe Conference Proceedings. abramis, Bury St Edmunds, Delphi, Greece.

Finnemann, Niels Ole (2005). Internettet i mediehistorisk perspektiv. København: Samfundslitteratur.

Freedman, Terry (ed.) (2006). Coming of age: an introduction to the new world wide web. http://fordlog.com/wpcontent/uploads/2006/04/Coming_of_age_v1-2.pdf.

Hull, Glynda (2003). Youth Culture and Digital Media: New Literacies for New Times, Research in the Teaching of English, Vol. 38(2).

iCrossing (2007). What is social media? www.icrossing.co.uk/ebooks 
Lukács, Mirko (2007). Education in the Transition to Public Service Media. In: Lowe, Gregory Ferrell \& Bardoel, Jo (eds.). From Public Service Broadcasting to Public Service Media, 199-214. Nordicom.

Løssing, Anne Sophie Warberg (2008). Danske kunstmuseer på nettet: en kortlægning og diskussion af en kunstmuseal formidling- og udstillingspraksis. Ph.d.-afhandling. Institut for Informations- og Medievidenskab, Aarhus Universitet.

Manovich, Lev (2001). The Language of New Media. The MIT Press. Cambridge, Massachusetts.

O'Reilly, T. (2005, 2007). What Is Web 2.0. Design Patterns and Business Models for the Next Generation of Software. http://www.oreillynet.com/lpt/a/6228.

Paulsen, Morten Flate (2003). Online education. Learning management systems. NKI Forlaget.

Sørensen, Birgitte Holm, Danielsen, Oluf \& Nielsen, Janni (2007). Children's informal learning in the context of school of knowledge society. Education and Information Technologies, 12(1) .

Sørensen, Birgitte Holm (2005). ICT and the Gab Between School Pedagogy and Children's Culture. Pedagogy, Culture and Society, 13 (nr. 1).

Willet, Rebekah \& Sefton-Green, Julian (2003). Living and Learning in Chatrooms (or does informal learning have anything to teach us?), Éducation et Sociétiés, vol. 2 (engelsk version af artikel publiceret i det franske tidsskrift).

Wilson, Scott, Liber, Oleg, Johnson, Mark, Beauvoir, Phil, Sharples, Paul \& Milligan, Colin (2006). Personal Learning Environments: Challenging the dominant design of educational systems, ECTEL 2006 Proceedings. http://dspace.learningnetworks.org/handle/1820/727 